\title{
BRUNO S. FREY I JOSEPH E. STIGLITZ O ZAWODNOŚCI PAŃSTWA I ZAWODNOŚCI RYNKU
}

\section{WSTĘP}

Od ponad pięciuset lat twórców myśli ekonomicznej nurtuje problem udziału państwa w życiu gospodarczym oraz sprawności działania rynku. W tym okresie powstały dziesiątki koncepcji na ten temat. Pod wpływem pewnych wydarzeń ekonomicznych, takich jak kryzysy, długotrwała prosperity, stagflacja, slumpflacja itp., zmianie ulegały nie tylko teoretyczne poglądy na temat roli państwa, ale również sposoby prowadzenia polityki gospodarczej. Co więcej, zakres działania państwa w gospodarce należy do fundamentalnych i najbardziej kontrowersyjnych zagadnień ekonomicznych, wyznaczających linię demarkacyjną między ekonomistami różnych szkół i kierunków.

Koncepcje zawodności państwa oraz zawodności rynku stały się przedmiotem badań przedstawicieli niemal wszystkich współczesnych szkół ekonomicznych. $Z$ przyczyn oczywistych największym zainteresowaniem cieszą się poglądy etatystów i antyetatystów. Niestety, mimo dużej wartości poznawczej rozważania na ten temat prowadzone przez Josepha E. Stiglitza oraz Brunona S. Freya pozostają - przynajmniej w polskim środowisku - na dalszym planie. Celem niniejszego opracowania jest więc wydobycie oryginalnych i niezwykle trafnych spostrzeżeń poczynionych przez wspomnianych uczonych, należących do różnych szkół ekonomicznych. Stiglitz jest amerykańskim ekonomistą, laureatem Nagrody Nobla w dziedzinie nauk ekonomicznych w 2001 roku, współtwórcą teorii niedoskonałej informacji, natomiast Frey jest ekonomistą szwajcarskim, współtwórcą ekonomicznej teorii polityki, zwanej w Europie nową ekonomią polityczną, a w USA - public choice. 


\section{EWOLUCJA POGLĄDÓW NA TEMAT EKONOMICZNEJ ROLI PAŃSTWA}

Problem ingerowania państwa w życie gospodarcze stał się przedmiotem rozważań ekonomicznych dopiero w czasach nowożytnych. Merkantyliści postulowali ochronę własnych rynków przed konkurencją zagraniczną oraz wspieranie uprzemysłowienia kraju ze strony państwa. Pierwszym orędownikiem liberalizacji wszelkiej działalności gospodarczej był Vincent Jean Claude Marie de Gournay, twórca hasła laissez faire, laissez passer, oznaczającego niewtrącanie się rządu do działalności ekonomicznej, czyli pozostawienie spraw gospodarczych ich własnemu biegowi. Hasło to przejęli i rozwinęli fizjokraci, z François Quesnayem na czele. W ich programie gospodarczym znalazły się: postulat wolności handlowej, wspierania konkurencji, ograniczania funkcji państwa, dla którego zastrzeżono obowiązek ochrony porządku naturalnego, rozwój edukacji oraz finansowanie robót publicznych i wreszcie opodatkowanie własności ziemskiej¹.

Twórca nauki ekonomia Adam Smith wykazał, że mechanizm rynkowy, nazwany „niewidzialną ręką rynku”, zapewnia sprawne funkcjonowanie społeczeństwa i gospodarki. Smith udowodnit, że rynek jest mechanizmem samoregulującym ceny, ilości dóbr i usług oraz dochody, mechanizmem scalającym społeczeństwo, a zarazem własnym strażnikiem. Jedynym warunkiem efektywnego funkcjonowania mechanizmu rynkowego jest jego nieskrępowane działanie. Największe niebezpieczeństwo systemu dostrzegał on w porozumieniach monopolistycznych, które zakłócają jego sprawne funkcjonowanie. Pogląd Smitha o korzyściach z ograniczenia roli państwa w gospodarce akceptowali i rozwijali pozostali twórcy szkoły klasycznej - od Davida Ricardo po Johna Stuarta Milla.

W 1885 roku przedstawiciel szkoły lozańskiej w Niemczech Carl Friedrich Wilhelm Launhardt wprowadził termin Marktversagen ${ }^{2}$, oznaczający zawodność rynku (ang. market failure), nazywany później zamiennie niesprawnością rynku albo defektami rynku. Nie wzbudził on wówczas większego zainteresowania ze strony ekonomistów. Karierę „zrobił” dopiero w drugiej połowie XX wieku. Pojęcie to oznacza sytuacje, gdy równowaga ustalona na konkurencyjnych rynkach nie zapewnia efektywnej alokacji zasobów. Innymi słowy, pojęcie to opisuje występowanie zakłóceń, które uniemożliwiają „niewidzialnej ręce” rynku zapewnienie efektywności ekonomicznej ${ }^{3}$.

Wielki Kryzys, który w latach 1929-1933 zdruzgotał większość ówczesnych potęg gospodarczych świata, obnażył słabości gospodarki rynkowej. Kata-

${ }^{1}$ Por. M. Bochenek, Wptyw ekonomistów na rozwój cywilizacji ludzkiej, „Acta Universitatis Nicolai Copernici” 2003, z. 367, s. 4.

${ }^{2}$ Por. F. Ritzmann, Bedeutende Oekonomen und ibre Werke. (Dogmenhistorische Chronik), Zentralstelle der Studentenschaft Zürich, Zürich 1983, s. 51.

${ }^{3}$ Por. D. Begg, S. Fischer, R. Dornbusch, Ekonomia, t. 1, PWE, Warszawa 1993, s. 442. 
strofalny spadek produkcji, masowe bezrobocie, ubóstwo itp. świadczyły wyraźnie, że mechanizm rynkowy zawiódł. Kurację gospodarki rynkowej zaproponował John Maynard Keynes. Uważał on, że gospodarka nie wyjdzie z kryzysu samoczynnie. Pobudzenie gospodarki miało nastąpić przez uruchomienie wydatków państwa, z których można finansować prace interwencyjne, budowę dróg, kanałów, lotnisk i domów mieszkalnych. $Z$ „nocnego stróża” państwo przekształciło się w ważnego inwestora. Rządowe programy wychodzenia z kryzysu nie miały być trwałym elementem systemu ekonomicznego, ale jedynie środkiem doraźnym, przeciwdziałającym zawodności rynku. Interwencjonizm państwowy powinien obejmować dziedziny, w które nie angażują się prywatne przedsiębiorstwa ${ }^{4}$.

W okresie powojennym niemal powszechnie akceptowano pogląd o potrzebie angażowania się państwa w sprawy gospodarki. Aktywnej polityce makroekonomicznej keynesiści przyznali zdolność wspomagania mechanizmu rynkowego, nazwaną „dostrajaniem”.

Interwencjonizm przynosił dobre rezultaty do końca lat 60. XX wieku. Wystąpienie stagflacji i slumpflacji w pierwszej połowie lat 70. w najwyżej rozwiniętych krajach świata doprowadziło do załamania paradygmatu keynesowskiego. Reakcją na niepowodzenia polityki keynesowskiej było odrodzenie neoliberalizmu, stanowiącego szeroki nurt antyinterwencjonistyczny, do którego - zdaniem Adama Lipowskiego, Krzysztofa Markowskiego i Andrzeja Wojtyny - należą monetaryzm, nowa ekonomia klasyczna, nowa szkoła austriacka, ekonomiczna teoria polityki oraz ekonomia strony podażowej ${ }^{6}$.

Niektórzy ekonomiści, m.in. Bronisław Minc, Mieczysław Mieszczankowski oraz Andrzej Wojtyna, zaproponowali nawet zastąpienie określenia „interwencjonizm państwowy", jako nieadekwatnego do ówczesnej gospodarki, pojęciem „ekonomiczna rola państwa”.

Zdaniem krytyków aktywnej roli państwa, trudności pojawiające się w gospodarce rynkowej wynikają z nadmiernego oddziaływania państwa, które zniekształca zasady swobodnej gry sił ekonomicznych. Friedrich August von Hayek

${ }^{4}$ Por. R. L. Heilbroner, Wielcy ekonomiści. Czasy-życie-idee, PWE, Warszawa 1993, s. 233-249, oraz R. Skarzyński, Państwo i spoteczna gospodarka rynkowa. Gtówne idee polityczne ordoliberalizmu, Instytut Studiów Politycznych Polskiej Akademii Nauk, Warszawa 1994, s. 32.

${ }^{5}$ Por. A. Wojtyna, Nowe trendy w zachodniej teorii ekonomii, Akademia Ekonomiczna w Krakowie, Kraków 1988, s. 97.

${ }^{6}$ Por. K. Markowski, Rola państwa w gospodarce rynkowej, wyd. 2 zm., PWE, Warszawa 1992, s. 7 i 24; A. Wojtyna, Nowoczesne państwo kapitalistyczne a gospodarka. Teoria i praktyka, PWN, Warszawa 1990, s. 55-66; oraz A. Lipowski, Ekonomiczna zawodność państwa-krytyczna analiza ujęcia antyetatystycznego, „Ekonomista” 2002, nr 2, s. 165.

${ }^{7}$ Por. B. Minc, Kapitalizm wspótczesny. Ekonomiczne problemy i tendencje rozwoju, wyd. 2 zm., PWN, Warszawa 1979, s. 319; M. Mieszczankowski, Monopol. Rozwój kapitalizmu od stadium wolnokonkurencyjnego do monopolistycznego i państwowo-monopolistycznego, t. 3, Książka i Wiedza, Warszawa 1982, s. 236; oraz A. Wojtyna, Nowoczesne..., s. 16 i 21-26. 
traktował ingerencję państwa jako największe zło zakłócające mechanizm rynkowy. Według Miltona Friedmana interwencja państwa stanowi zagrożenie dla wolności indywidualnej, natomiast ograniczenie zaangażowania rządu prowadzi do wyższego wzrostu gospodarczego i stabilizacji gospodarki. Z krytyką aktywnego oddziaływania państwa wystąpił również George J. Stigler, uważając, że nie są znane efekty realizowanej przez państwo polityki ekonomicznej. Na bezsilność rządu w sferze gospodarki wykazywali również twórcy nowej ekonomii klasycznej - Robert E. Lucas, Thomas J. Sargent i Neil Wallace. Przedstawiciele tej szkoły proponują ograniczenie interwencji państwa zgodnie z hasłem „mniej rządu”, a także przywrócenie do życia samoczynnego mechanizmu rynkowego, który prowadzi gospodarkę do równowagi ${ }^{8}$.

Antyetatyści postulowali, aby państwo samodzielnie „wycofywało się” z gospodarki, czyli żeby nastąpiło świadome samoograniczenie roli państwa w życiu gospodarczym oraz przywrócenie - w możliwie szerokim zakresie - samoregulującego mechanizmu rynkowego9. Pogląd twórców nowej ekonomii klasycznej o braku miejsca dla aktywnej polityki gospodarczej odrzucił Franco Modigliani i ocenił jako absurdalny oraz oderwany od rzeczywistości ${ }^{10}$.

Zdaniem zwolenników aktywnej roli państwa niepowodzenia w dostrajaniu gospodarki świadczą o trudnościach i złożoności sterowania gospodarką ${ }^{11}$. Niedoskonałości rynku stanowią uzasadnienie dla ingerencji instytucji rządowych ${ }^{12}$. Nieskuteczność niektórych programów rządowych nie powinna być - według K. Markowskiego - traktowana jako argument przeciwko idei interwencjonizmu w ogóle. Należy raczej poszukiwać skuteczniejszych metod oddziaływania państwa na gospodarkę. Co więcej, autor ten zaliczył interwencjonizm państwowy do trwałych cech współczesnych gospodarek rynkowych ${ }^{13}$.

Liberałowie - jak zauważył Adam Lipowski - podkreślali, że jeśli państwo nie psuje rynku, wówczas działa on sprawnie, a jego „strojenie” jest nie tylko niepotrzebne, ale wręcz szkodliwe. Mniej radykalni antyetatyści przyznawali z kolei, że rynek może wprawdzie zawodzić w niektórych sytuacjach, to jednak nie daje to wystarczających podstaw do ingerencji państwa. Dopuszczali oni możliwość interwencji, jeśli przyniesie ona korzyści gospodarce w postaci zredukowanych

\footnotetext{
${ }^{8}$ Por. K. Markowski, op. cit., s. 24-27.

${ }^{9}$ Por. A. Wojtyna, Nowoczesne..., s. 22.

${ }^{10}$ Por. idem, Nowe..., s. 104.

${ }^{11}$ Por. ibidem, s. 103.

${ }^{12}$ Por. K. Markowski, op. cit., s. 20 i 23; oraz M. Belka, Ewolucja poglądów teoretycznych na temat roli państwa w gospodarce, [w:] Ekonomiczne strategie krajów wysoko rozwiniętych, red. M. Belka, Zakład Narodowy im. Ossolińskich-Wydawnictwo PAN, Wrocław-Warszawa-Kraków 1992, s. 10.

${ }^{13}$ Por. K. Markowski, op. cit., s. 7 i 27.
} 
strat wywołanych przez zawodny rynek. Jednakże trudności przysparza ich kwantyfikacja $\mathrm{a}^{14}$.

Twierdzenia na temat zawodności państwa oraz zawodności rynku nie są zdaniem A. Lipowskiego - efektem uogólnień sformułowanych na podstawie badań empirycznych o zasięgu światowym, są więc jedynie zborem hipotez roboczych. Mimo braku empirycznej weryfikacji antyetatystycznych twierdzeń na temat ekonomicznej zawodności państwa, koncepcja ta odegrała ważną rolę w rozwoju myśli ekonomicznej oraz polityki gospodarczej. Uświadomiła ona ekonomistom oraz szerszej opinii publicznej, że niesprawność rynku nie jest wystarczającym argumentem na rzecz ingerencji państwa w gospodarkę oraz potrzeby zwiększania jej skuteczności. Również pod wpływem poglądów antyetatystycznych nastąpiła istotna redukcja roli państwa w wielu gospodarkach świata ${ }^{15}$.

Adam Lipowski sceptycznie podchodził do akademickiej koncepcji zawodności rynku, z uwagi na jej jednoczesne nadmierne uogólnienie i niedostateczną uniwersalność. Postulował więc urealnienie dotychczasowego ujęcia tej koncepcji poprzez empiryczną konkretyzację analizy sprawności (zawodności) rynku, uwzględniające specyficzne cechy rynków krajowych, a także uzupełnienie jej o koncepcję zawodności państwa ${ }^{16}$.

Rozważania na temat ekonomicznej zawodności państwa mają ogromną zaletę praktyczną, pozwalają one bowiem usprawnić lub wyeliminować nieskuteczne rodzaje polityki ekonomicznej, czyli te rodzaje polityki, które nie są w stanie zredukować strat wywołanych zawodnością rynku ${ }^{17}$.

Przeregulowanie rynku ze strony państwa prowadzi do jego psucia, a w efekcie do jego zawodności. Państwo powinno wówczas podjąć działania deregulacyjne. Interwencjonizm okazuje się więc nieuzasadniony w przypadkach niedostrzegania przez ekonomię zawodności rynku - konstatował A. Lipowski ${ }^{18}$.

\section{POGLĄDY JOSEPHA E. STIGLITZA NA TEMAT NIESPRAWNOŚCI RYNKU I NIESPRAWNOŚCI PAŃSTWA}

Joseph E. Stiglitz uważa, że współcześni ekonomiści są zgodni w kwestiach ogólnych. Akceptują oni pogląd, że rynek i prywatna przedsiębiorczość zapew-

\footnotetext{
${ }^{14}$ Por. A. Lipowski, Ekonomiczna..., s. 165.

${ }^{15}$ Por. ibidem, s. 182 i $187-188$.

${ }^{16}$ Por. A. Lipowski, O akademickiej koncepcji zawodności rynku krytycznie, „Ekonomista” 2001, nr 3, s. 318-319.

${ }^{17}$ Por. idem, Ekonomiczna..., s. 166.

${ }^{18}$ Por. A. Lipowski, O akademickiej..., s. 317-318.
} 
niają trwały rozwój gospodarki, natomiast państwo, które wprawdzie pozostaje ważnym podmiotem, powinno odgrywać jedynie rolę uzupełniającą ${ }^{19}$.

\section{ZAWODNOŚĆ RYNKU}

W swym monumentalnym dziele pt. Ekonomia sektora publicznego Stiglitz wymienia sześć rodzajów (form) zawodności rynku, będących głównymi przyczynami nieefektywności rynku w rozumieniu Pareta ${ }^{20}$ :

1. Zawodność konkurencji. Istnienie doskonałej konkurencji zapewnia każdej gospodarce efektywność w ujęciu Pareta. Natomiast występowanie ograniczeń konkurencji (konkurencja monopolistyczna, monopol naturalny, patenty itp.) wywołuje nieefektywność ekonomiczną związaną z ograniczeniem produkcji i stratą dobrobytu.

2. Zawodność wynikająca $\mathrm{z}$ istnienia dóbr publicznych. Rynki prywatne albo nie dostarczają w ogóle czystych dóbr publicznych, albo w niewystarczającej ilości. Dobra te, takie jak obrona narodowa, ochrona przeciwpożarowa i usługi policji, posiadają dwie właściwości, tj.: niemożność wykluczenia i brak rywalizacji (konsumpcja nierywalizacyjna). Istnienie tych dóbr prowadzi do powstania zawodności rynku.

3. Zawodność wynikająca z efektów zewnętrznych. Do efektów zewnętrznych zalicza się działania pojedynczych osób lub przedsiębiorstw, które wywierają wpływ na sytuację innych jednostek i przedsiębiorstw. W przypadku negatywnych efektów zewnętrznych jednostki nie ponoszą pełnych kosztów swojej działalności oraz nie wypłacają żadnego odszkodowania, mimo że przynoszą szkody innym jednostkom. W przypadku pozytywnych efektów zewnętrznych działania jednostek przysparzają korzyści innym jednostkom, nie otrzymując w zamian za to rekompensat. Produkcja towarów wywołujących ujemne efekty zewnętrzne na ogół jest nadmierna, natomiast podaż towarów wywołujących dodatnie efekty zewnętrzne jest niedostateczna. W tych przypadkach mechanizm rynkowy nie zapewnia efektywnej alokacji zasobów. Występowanie efektów zewnętrznych prowadzi więc do nieefektywności rynku.

4. Niekompletność (brak) rynków. Ten rodzaj zawodności rynku występuje wówczas, gdy prywatne rynki nie wytwarzają odpowiedniej ilości dóbr i usług, chociaż koszt produkcji jest niższy od ceny akceptowanej przez po2004, s. 7.

${ }^{19}$ Por. J. E. Stiglitz, Ekonomia sektora publicznego, Wydawnictwo Naukowe PWN, Warszawa

${ }^{20}$ Por. ibidem, s. $90-101,150-151,177,254-256,286,297-298,412$, 430-436, 513-514 i 890 . 
tencjalnych nabywców. Do niekompletnych rynków zalicza się rynki ubezpieczeniowe oraz rynek kapitałowy. Ponieważ prywatne rynki nie oferują ubezpieczeń wkładów bankowych, zbiorów płodów rolnych, ubezpieczeń od skutków powodzi, od pożaru w pewnych obszarach, na wypadek bezrobocia, zdrowotnych dla osób starszych itp., ubezpieczenia od tych rodzajów ryzyka oferuje państwo.

5. Zawodność wynikająca $z$ niepełnej informacji (niedoskonałość informacji). Ponieważ prywatny rynek nie zapewnia konsumentom i inwestorom właściwej ilości informacji, państwo - poprzez programy publiczne - nakłada na podmioty oferujące dobra i usługi obowiązek przekazywania pełnej informacji o swych produktach. $Z$ tego też względu pełna informacja przypomina dobra publiczne, które nie są dostarczane w odpowiedniej ilości. Przykładami działań państwa, które stawia sobie za cel zapobieganie zawodności rynku związanej z niepełną informacją, są prognozy pogody oraz wiedza uzyskana z badań i prac rozwojowych $(B+R)$. Niedoskonałość informacji wywołuje również inne rodzaje zawodności rynku.

6. Zakłócenia makroekonomiczne. Niepełne zatrudnienie, czyli bezrobocie i niezaangażowany zasób kapitału rzeczowego, stanowi najbardziej dramatyczny i widoczny przejaw zawodności rynku. Innymi rodzajami zakłóceń makroekonomicznych, świadczącymi o zawodności rynku, są inflacja, nierównowaga rynkowa i deficyt budżetowy.

Powyższe rodzaje zawodności rynku, prowadzące do ekonomicznej nieefektywności w rozumieniu Pareta, uzasadniają - zdaniem Stiglitza - ingerencję państwa w mechanizm rynkowy. Ale zapobieganie zawodności rynku często bywa nieskuteczne, natomiast cele programów publicznych mają charakter polityczny, względnie ukrywają wpływy określonych grup interesu. Państwo może również bezpośrednio angażować się w produkcję dóbr publicznych, albo ograniczyć się do jej sfinansowania. Laureat Nagrody Nobla podkreśla że interwencja państwa na rynku znajduje uzasadnienie tylko wtedy, gdy jego działalność ograniczy zawodność rynku i przyniesie korzyści w rozumieniu Pareta, czyli zapewni poprawę sytuacji niektórych jednostek, nie pogarszając równocześnie sytuacji kogoś innego ${ }^{21}$.

Zdaniem amerykańskiego ekonomisty najbardziej jaskrawym przykładem zawodności rynku był Wielki Kryzys. Występujące wówczas masowe bezrobocie i katastrofalny spadek produkcji były niezbitym dowodem, że zawiodła niewidzialna ręka rynku. W obliczu tych dramatów przekonująca wydawała się propozycja J. M. Keynesa, aby państwo podjęło działania mające na celu stabilizację gospodarki i uniknięcie recesji. Mechanizm rynkowy okazał się bowiem niezdol-

${ }^{21}$ Por. ibidem, s. 70, 90, 95, 103, 107, 221 i 299. 
ny do ograniczenia bezrobocia i zwiększenia zatrudnienia. Równie dotkliwe były bankructwa banków i bessa na giełdzie, na skutek których ludność straciła niemal wszystkie oszczędności, natomiast słabsze grupy społeczne zostały skazane na życie w nędzy. Na skutek trudności spłaty długów powszechnym zjawiskiem stały się bankructwa farmerów i przejmowanie ich gospodarstw przez banki. Rządy niektórych krajów zastosowały wówczas narzędzia stabilizujące aktywność gospodarczą oraz wprowadziły w życie system ubezpieczeń społecznych, ubezpieczenia na wypadek bezrobocia oraz ubezpieczenia dla posiadaczy wkładów bankowych, a także ceny minimalne na płody rolne. Po II wojnie światowej realizowano programy powszechnej edukacji zwiększającej możliwości zatrudnienia oraz podjęto walkę z ubóstwem i rozwarstwieniem społecznym poprzez wprowadzenie nowych programów pomocy społecznej. Obejmowały one powszechny dostęp do służby zdrowia, poprawę poziomu wyżywienia, szkolenia zawodowe oraz przedszkola dla dzieci z najuboższych rodzin. Działania te miały na celu zwiększenie możliwości awansu ekonomicznego szerszym warstwom społecznym. Po kilkudziesięciu latach okazało się, że tylko niektóre działania doprowadziły do rozwiązania drażliwych problemów. Przykładowo, rządowy program pomocy medycznej osobom uboższym zwiększył dostęp do opieki zdrowotnej, ale nie zlikwidował różnic w długości życia między bogatymi i biednymi. Podobnie program opieki medycznej osób starszych zapewnił tej grupie dostęp do usług medycznych, jednakże został okupiony nieoczekiwanym wzrostem wydatków na ochronę zdrowia. Coraz większe wątpliwości budzi również program ubezpieczeń społecznych, który wprawdzie zagwarantował osobom starszym niespodziewanie wysoki poziom bezpieczeństwa socjalnego, jednakże $z$ uwagi na ogromne problemy finansowe system ten w przyszłości może okazać się mniej wydajny. Zupełnym fiaskiem zakończyła się wojna z ubóstwem, twierdził Stiglitz ${ }^{22}$.

Chociaż celem niektórych programów rządowych było - jak przyznaje amerykański noblista - usprawnienie rynku, to jednak przyniosły one przeciwne skutki. Realizując program poprawy warunków mieszkaniowych niezamożnej ludności w centrach miast, wyburzono stare domy oraz wzniesiono nowe o wyższym standardzie. Opłaty za nowe mieszkania zmniejszyły dostęp dla osób uboższych, skazując je na życie w jeszcze gorszych warunkach. Program ten przyczynił się również do zwiększenia bezdomności. Wprowadzenie czynszów regulowanych w Nowym Jorku miało zahamować ich wzrost oraz udostępnić mieszkania osobom mniej zamożnym. Efektem pominięcia podstawowych praw rynku było zmniejszenie podaży domów i mieszkań na wynajem oraz pogorszenie jakości usług mieszkaniowych. $Z$ kolei z programów pomocy dla rolnictwa w największym stopniu skorzystały duże gospodarstwa farmerskie, podczas gdy znaczna

${ }^{22}$ Por. ibidem, s. 7-9. 
część małych gospodarstw została skazana na upadek. Tylko częściowo powiódł się program integracji dzieci różnych ras w amerykańskich szkołach publicznych. Z przytoczonych przykładów Stiglitz wywnioskował, że zawodność rynku stanowi ważny motyw oddziaływania państwa na gospodarkę $e^{23}$.

\section{ZAWODNOŚĆ PAŃSTWA}

Według autora Ekonomii sektora publicznego zawodności rynku miały zostać ograniczone przez programy publiczne podejmowane przez państwo. Niestety, wiele $z$ nich nie przyniosło oczekiwanych efektów. Ich nieskuteczność świadczyła o zawodności państwa. Amerykański ekonomista wymienia cztery główne przyczyny zawodności państwa ${ }^{24}$ :

1. Ograniczony zasób dostępnej informacji. $Z$ uwagi na brak pełnej informacji oraz złożoność pewnych zjawisk, efekty wielu decyzji i działań państwa są nieprzewidywalne. Brak niezbędnej informacji uniemożliwia również realizację odpowiednich programów publicznych. Przykładowo objęcie wszystkich osób niepełnosprawnych systemem pomocy społecznej utrudnia brak informacji o rzeczywistej niesprawności osób ubiegających się o pomoc publiczną.

2. Ograniczona kontrola nad skutkami działań państwa na prywatnych rynkach. Państwo nie jest w stanie sprawować bezpośredniej i pełnej kontroli nad sposobami wykorzystania środków publicznych.

3. Ograniczona kontrola nad biurokracją dotyczy przypadków, gdy agencje rządowe opracowują przepisy wykonawcze wypaczające intencje twórców prawa oraz gdy nie egzekwują obowiązujących przepisów.

4. Ograniczenia o charakterze politycznym obejmują poczynania rządu, których realizacje są uzależnione od decyzji politycznych. Nierzadko parlamentarzyści ulegają naciskom tych grup interesu, które finansują kampanie wyborcze. Natomiast nieświadomi i naiwni wyborcy upraszczają otaczającą rzeczywistość oraz poszukują prostych rozwiązań złożonych problemów.

Dla przeciwników oddziaływania państwa na gospodarkę, twierdzi Stiglitz, wspomniane źródła zawodności państwa stanowią wystarczający argument na rzecz zaniechania interwencji $\mathrm{w}$ gospodarkę oraz podejmowania prób naprawy mechanizmu rynkowego. Tymczasem zawodzą również rynki. Jednakże próby usprawniania mechanizmu rynkowego podejmowane przez niektóre rządy na ogół zakończyły się niepowodzeniem. Oznacza to, że ani rynek, ani państwo nie działają doskonale, czyli niezawodnie, uważa amerykański laureat Nagrody

\footnotetext{
${ }^{23}$ Por. ibidem, s. 9-10.

${ }^{24}$ Por. ibidem, s. $10-12$.
} 
Nobla. Skoro państwo działa w sposób niedoskonały, to należy ograniczyć jego interwencję tylko do tych przypadków, gdy zawodność rynku jest większa oraz interwencja okaże się skuteczna w rozwiązywaniu określonych problemów. Zdaniem wielu ekonomistów amerykańskich - jak podaje Stiglitz - państwo powinno interweniować w sposób ograniczony oraz dążyć do złagodzenia (a nie rozwiązania) najbardziej nurtujących problemów społeczno-gospodarczych. Priorytetowe cele obejmują zapewnienie pełnego zatrudnienia oraz likwidację biedy. Głównymi filarami współczesnej gospodarki powinny pozostać przedsiębiorstwa prywatne. Zamiast przeciwstawiać państwo rynkowi i odwrotnie należy szukać płaszczyzny współdziałania, prowadzącego do wzajemnego wzmocnienia. Osiągniecie tego celu jest możliwe pod warunkiem opierania działalności państwa na mechanizmie rynkowym ${ }^{25}$.

Wyjaśniając motywy objęcia stanowiska przewodniczącego Zespołu Doradców Ekonomicznych prezydenta USA, w publikacji poświęconej problemom globalizacji, Stiglitz pisał:

Starałem się wypracować politykę gospodarczą i filozofię, które by traktowały państwo i rynek jako uzupełniające się nawzajem i współdziałające oraz dostrzegały, iż wprawdzie rynek zajmuje centralne miejsce w gospodarce, państwo jednak też ma do odegrania ważną, aczkolwiek ograniczoną, rolę. Studiowałem zawodność zarówno rynku, jak i państwa, i nie byłem tak naiwny, aby myśleć, że państwo może naprawić każde niepowodzenia rynku. Nie byłem też na tyle niemądry, aby sądzić, iż rynek sam z siebie rozwiąże wszelkie problemy społeczne. Nierówności, bezrobocie, zanieczyszczenie środowiska - wszystko to były sprawy, w których państwo musiało odgrywać ważną rolę ${ }^{26}$.

\section{ZAWODNOŚĆ PAŃSTWA I ZAWODNOŚĆ RYNKU W UJĘCIU BRUNONA S. FREYA}

Bruno S. Frey nie ma wątpliwości, że to właśnie prywatne rynki umożliwiają społeczeństwom osiągnąć dobrobyt. Jednakże sprawne funkcjonowanie rynkowego systemu cen jest możliwe pod warunkiem istnienia odpowiednich instytucji. Działanie rynku musi być obwarowane wyraźnie określonymi prawami, m.in. prawem własności, oraz wsparte sprawnie działającymi organami administracji publicznej i sądownictwa. Warunkiem efektywnie funkcjonującego rynku jest więc silne państwo. Równie ważny dla systemu rynkowego jest elementarny poziom wzajemnego zaufania ${ }^{27}$.

${ }^{25}$ Por. ibidem, s. $12-13$.

${ }^{26}$ Por. J. E. Stiglitz, Globalizacja, Wydawnictwo Naukowe PWN, Warszawa 2004, s. 10.

${ }^{27}$ Por. B. S. Frey, Transformation - what is the role of the State?, Seminar Papers No. 8, Cracow Academy of Economics - Friedrich Ebert Fundation, Cracow 1992, s. 11-12. 


\section{ZAWODNOŚĆ RYNKU}

Szwajcarski ekonomista utrzymuje, że w niektórych sytuacjach mechanizm rynkowy działa w sposób zawodny. Frey wymienia pięć okoliczności, w których zacina się mechanizm rynkowy:

1. Producent lub konsument posiada na tyle silną pozycję, że pozwala ona narzucić partnerowi koszty bez jego akceptacji.

2. Państwo zapewnia dostęp do pewnych dóbr, dlatego ograniczenie dostępu staje się niemożliwe.

3. Produkcja masowa pozwala osiągnąć korzyści skali, dzięki którym firmy stają się monopolistami na danym rynku.

4. Wysokie ryzyko towarzyszące niektórym przedsięwzięciom zabija ducha przedsiębiorczości i dany rynek cechuje zbyt słaba dynamika.

5. Uczestnicy „gry rynkowej” nie mają dostępu do pełnej informacji.

W sytuacjach, gdy rynek jest zawodny, państwo - według jego zwolenników - powinno oddziaływać na gospodarkę w celu likwidacji wypaczeń. Zdaniem ekonomisty z Zurychu w ten sposób w przeszłości usprawiedliwiano rządowe programy, które miały naprawić niesprawny rynek. Obejmowały one politykę antymonopolową, programy socjalne, takie jak: publiczna opieka zdrowotna nad osobami starszymi oraz socjalne budownictwo mieszkaniowe, a także rządowe programy wspierające innowacje technologiczne. Również obecnie nie brakuje zwolenników takiego traktowania państwa. Według ich założeń państwo przypomina dobrotliwego dyktatora, który chce zapewnić społeczeństwu szczęście. Takie rozumowanie zawierała ekonomia keynesowska, postulująca prowadzenie polityki stabilizacyjnej. W jej ramach zalecano wzrost wydatków budżetowych $\mathrm{w}$ fazie recesji i ich ograniczanie $\mathrm{w}$ fazie boomu. Również przedstawiciele nowej teorii finansów - neoklasycznej „public economics” - proponują optymalne podatki i optymalne ceny dóbr dostarczanych przez państwo (elektryczność, usługi transportowe itp.), które umożliwiają społeczeństwu osiągnąć wyimaginowany dobrobyt. Natomiast twórcy nowej ekonomii politycznej dokonali rewizji tych poglądów. Według ich teorii państwo nie stanowi organicznej jedności, dlatego też należy raczej analizować zachowania poszczególnych polityków i urzędników publicznych. Podobnie jak inni ludzie, również oni kierują się celami osobistymi, dążą do osiągnięcia wysokich dochodów, zdobycia władzy i wpływów, a także unikania konfliktów. Oznacza to, że działania polityków i biurokratów są sprzeczne z życzeniami społeczeństwa oraz obce jest im dobro publiczne ${ }^{28}$.

${ }^{28}$ Por. B. S. Frey, G. Kirchgässner, Demokratische Wirtschaftspolitik. Theorie und Anwendung, 2. Auf., Verlag Franz Vahlen, München 1994, s. 87-98, 139-140 i 456; B. S. Frey, Die Rolle des Staates in der Wirtschaft, „Neue Zürcher Zeitung” 1991, Nr. 242, s. 38; idem, Moderne Politische Ökonomie. Die Beziehungen zwischen Wirtschaft und Politik, R. Piper \& Co. Verlag, München-Zü- 


\section{ZAWODNOŚĆ PAŃSTWA}

Ekonomiczna teoria polityki - na co zwraca uwagę Frey - przypisuje współczesnemu państwu cztery właściwości, które sprawiają, że również ono jest niesprawne:

1. Związki zawodowe, rolnicy i producenci wyrobów przemysłowych, jako lepiej zorganizowane grupy społeczne, są permanentnie faworyzowani (uzyskując różnego rodzaju dotacje, subwencje, ochronę celną itd.) w porównaniu z konsumentami i podatnikami, którzy nie mają swoich organizacji. Państwo ukrywa koszty swojej działalności (czemu sprzyjają lubiane przez polityków i biurokratów podatki pośrednie), względnie przerzuca je na konsumentów i podatników. Przykładowo, koszty polityki protekcjonistycznej, chroniącej krajowych producentów przed konkurencją zagraniczną, obciążają budżety gospodarstw domowych, które płacą wyższe ceny oraz podatki.

2. Nazbyt często i chętnie rządzący ingerują w życie gospodarcze pod pozorem działalności w interesie wyborców, gdy tymczasem wzmacniają swoją władzę. Świadczą o tym chociażby drobiazgowe przepisy w sprawie ochrony środowiska naturalnego.

3. Politycy i biurokraci czerpią korzyści ze świadomie tworzonej nierównowagi na niektórych rynkach, m.in. ustalają ceny maksymalne, w efekcie których pojawia się niedobór, będący podstawą do wprowadzenia reglamentacji dóbr. Są one przyznawane uznaniowo jednostkom i grupom, które są przychylne danym politykom i urzędnikom.

4. Demokratycznie wybrani politycy tak sterują procesami gospodarczymi, aby doprowadzić do pogorszenia sytuacji gospodarczej kraju. Zgodnie z teorią politycznego cyklu koniunkturalnego ${ }^{29}$ rządy celowo wywołują recesję po wyborach parlamentarnych lub prezydenckich, aby przed wyborami gospodarka osiągnęła wysoki wzrost ekonomiczny oraz wystąpił spadek bezrobocia. Z kolei urzędnicy dążą do uniknięcia błędów formalnych. Niestety, koncentrowanie uwagi na biurokratycznych procedurach pociąga wysokie koszty.

Opisane wyżej przypadki nie należą do incydentów lub teoretycznych rozważań. Ich występowanie potwierdzają badania empiryczne prowadzone w wielu krajach. Wynika $\mathrm{z}$ nich, że ingerowanie instytucji rządowych w gospodarkę

rich 1977, s. 21 i n.; idem, Internationale Politische Ökonomie, Verlag Franz Vahlen, München 1985, s. 126; idem, Transformation..., s. 9; oraz idem, Ökonomie ist Sozialwissenschaft. Die Anwendung der Ökonomie auf neue Gebiete, Verlag Franz Vahlen, München 1990, s. 146.

${ }^{29}$ Twórcą tej teorii był nie tylko Bruno S. Frey, który ogłosił ją w pracy pt. Theorie und Empirie Politischer Konjunkturzyklen (1976), ale również William Nordhaus - The Political Business Cycle (1975) oraz Edward Tufle - Political Control of the Economy (1978). 
w większości przypadków wywołuje negatywne skutki. Oznacza to, że równiė̇ państwo działa w sposób zawodny.

Ekonomista szwajcarski podkreśla, że ingerencja państwa nie zawsze jest właściwa, gdy zawodzi rynek. Postuluje on, aby w każdym przypadku badać i porównywać koszty funkcjonowania rynku oraz koszty ingerencji państwa. Zadaniem państwa nie jest bowiem bezpośrednie i odręczne sterowanie gospodarką, ale tworzenie „reguł gry ekonomicznej”, tj. warunków ramowych działania prywatnych podmiotów. Państwo powinno więc unikać systematycznej ingerencji. Aby państwo uwzględniało preferencje obywateli, należy - zdaniem Freya - rozszerzyć ich udział w życiu politycznym. Możliwość taką, jak pokazują rozwiązania szwajcarskie, dają referendum i federalizm. Aktywny udział obywateli w życiu politycznym wymusza na państwie realizację życzeń obywateli oraz hamuje ekspansję państwa w gospodarkę $e^{30}$.

$Z$ uwagi na różne rodzaje niesprawności rynek nie zapewnia stanu optymalnego. Dlatego też przedstawiciele różnych szkół proponują - jako niezbędną - interwencję państwa w gospodarkę. Zakładają przy tym, że celem rządu jest osiąnięcie społecznego optimum, któremu podporządkowane są jego działania. To nastawienie technicystyczne (dążenie do optimum) przysłania orientację humanistyczną. W teoriach tych Frey dostrzega błąd, gdyż pomijają one ważny z punktu widzenia ekonomicznej teorii polityki fakt, że rządy tworzone są przez polityków i administratorów, dążących do osiąnięcia partykularnych korzyści. W praktyce więc politycy i biurokraci nie dążą do artykułowanego przez siebie „dobra publicznego”. Politycy i biurokraci są więc zainteresowani poszerzaniem zakresu rządowej interwencji w gospodarkę, aby w zamian za poparcie przyznawać korzyści dobrze zorganizowanym grupom. Zachowania te świadczą - zdaniem niektórych ekonomistów - o niesprawności państwa. W celu jej przezwyciężenia proponują poszerzenie działalności rynku. Ich rozumowanie przypomina propozycję rozwiązania problemu niesprawności rynku. I jedni, i drudzy wierzyli, że lekarstwem na zawodność jednego mechanizmu (rynek lub państwo) jest mechanizm konkurencyjny. Twierdzenie, że niesprawny jest tylko rynek albo niesprawne jest tylko państwo, jest twierdzeniem naiwnym. Nie ma bowiem żadnych dowodów, że jeśli państwo działa niesprawnie, to rynek będzie działał doskonale, i odwrotnie. Wynika to stąd, że zawodność państwa albo (i) zawodność rynku jest wynikiem wpływu tych samych uwarunkowań. Zamiast porównywać konkretną rzeczywistość z idealnym społecznym optimum, omawiany ekonomista z Zurychu zaleca analizę porównawczą, który mechanizm alokacji zasobów (rynek czy

${ }^{30}$ Por. B. S. Frey, G. Kirchgässner, op. cit., s. 87, 139 i 201-218 i 299-334; B. S. Frey, Die Rolle..., s. 38; idem, Moderne..., s. 139 i n.; idem, Transformation..., s. 9-10; oraz B. S. Frey, R. Eichenberger, The New Democratic Federalism for Europe: Functional, Overlapping and Competing Jurisdictions, Edward Elgar, Cheltenham-Northampton 1999, s. 3 i n. 
państwo) umożliwia realizację konkretnego celu społeczno-gospodarczego. Błędem jest również - konstatował Frey - pomijanie innych mechanizmów i możliwości społecznych rozwiązań, istniejących we współczesnych społeczeństwach ${ }^{31}$.

\section{ZAKOŃCZENIE}

Zagadnienie roli państwa oraz mechanizmu rynkowego w życiu gospodarczym zajmuje centralną pozycję w rozważaniach ekonomicznych od 500 lat. W dobie merkantylizmu państwo - na podstawie przyznanych uprawnień i instrumentów - przejęło funkcję podstawowego regulatora procesów gospodarczych, od produkcji, poprzez wymianę, aż po podział. Adam Smith uzasadnił ograniczenie udziału państwa w gospodarce do niezbędnego minimum (rola ta została opacznie nazwana przez Ferdynanda Lassalla rolą „nocnego stróża”). Dla „ojca” ekonomii niczym nieskrępowany mechanizm rynkowy zapewnia pożądaną ze społecznego punktu widzenia alokację zasobów. Smithowska myśl liberalna dominowała w ekonomii do czasu Wielkiego Kryzysu, który obnażył nieskuteczność rynku w rozwiązywaniu problemów recesji, bezrobocia i ubóstwa. Remedium na bolączki ówczesnego kapitalizmu miała być rewolucyjna propozycja Johna Maynarda Keynesa w postaci interwencjonizmu państwowego w gospodarkę. Jednakże wystąpienie stagflacji i slumpflacji w latach 70. XX wieku było impulsem do odrodzenia liberalizmu, który szybko zdominował akademicką myśl ekonomiczną. Do toczącej się między neoklasykami i keynesistami dyskusji na temat zawodności rynku oraz zawodności państwa włączają się przedstawiciele różnych szkół i kierunków, wnosząc nowe ujęcia i tematy. Interesujące rozstrzygnięcia tych problemów zaproponowali m.in. Joseph E. Stiglitz oraz Bruno S. Frey.

Joseph E. Stiglitz zwraca uwage na to, że zidentyfikowane rodzaje zawodności rynku (niedoskonałość konkurencji, istnienie dóbr publicznych i efektów zewnętrznych, brak rynków, niedoskonałość informacji oraz zakłócenia makroekonomiczne) prowadzą do jego nieefektywności w sensie Pareta. W tych sytuacjach niektóre rządy ulegają pokusie zwiększenia zaangażowania się w życie gospodarcze. Zdaniem amerykańskiego ekonomisty ma ono uzasadnienie tylko w przypadku możliwości ograniczenia zawodności rynku. Niestety, ekonomiczna działalność państwa również naznaczona jest niesprawnością, m.in. z powodu braku pełnej informacji, ograniczonej kontroli nad działaniem prywatnych rynków, ograniczonej kontroli nad biurokracją oraz ograniczeń o charakterze politycznym. Stiglitz proponuje współdziałanie państwa i rynku zamiast ich konfrontacji. Traktowanie państwa i rynku jako komplementarnych instytucji i mechanizmów

\footnotetext{
${ }^{31}$ Por. B. S. Frey, Transformation..., s. 11-14.
} 
alokacji zasobów może doprowadzić do ich wzmocnienia oraz zwiększenia skuteczności rozwiązywania określonych problemów społeczno-gospodarczych.

$\mathrm{Z}$ kolei Bruno S. Frey zwraca uwagę, że sprawne funkcjonowanie prywatnych rynków wymaga istnienia silnego państwa. Tworzone przez państwo prawo i instytucje stanowią ramy działania rynku, czyli tzw. reguły gry ekonomicznej. Niestety, zawodzi zarówno mechanizm rynkowy, jak i państwo. Zbyt silny partner narzucający warunki kontraktu, pełny dostęp do dóbr publicznych, istnienie monopoli, wysokie ryzyko niektórych przedsięwzięć oraz niepełna informacja moga doprowadzić do niesprawności rynku. Państwo nie powinno jednak w każdym przypadku zastępować niesprawnego rynku. Próby likwidacji wypaczeń rynku przez państwo mogą okazać się nietrafione $\mathrm{z}$ uwagi na zawodność tegoż państwa. Do niesprawności państwa przyczyniają się m.in.: silne i dobrze zorganizowane grupy społeczne, nadmiar przepisów prawnych regulujących współżycie społeczne, świadome tworzenie nierównowagi na poszczególnych rynkach oraz destabilizacja koniunktury gospodarczej. Dlatego też Frey proponuje porównywanie kosztów i korzyści działania państwa oraz rynku, a rozwiązanie konkretnych problemów społeczno-gospodarczych przekazać sprawniejszemu (tańszemu) mechanizmowi alokacji zasobów. Nie mniej ważne jest zwiększenie udziału społeczeństwa w rozwiązywaniu jego problemów.

Atrakcyjne intelektualnie rozwiązania zaproponowane przez Josepha E. Stiglitza i Brunona S. Freya znajdują zastosowanie w wielu krajach. Należy mieć nadzieję, że zostaną również wykorzystane w polskiej polityce gospodarczej.

\section{BRUNO S. FREY AND JOSEPH E. STIGLITZ ABOUT GOVERNMENT FAILURE AND MARKET FAILURE}

SUMMARY

One of the most fascinating economic issues is the effectiveness of the operating of resources allocation mechanisms. During 250 years, mercantilists were favouring a nation; later Adam Smith convincingly substantiated, that only the market mechanism enables nations to achieve prosperity, however John Maynard Keynes postulated - during the Great Depression - a state intervention in economy. New more sublime arguments have appeared on the issue of market failure and government failure. Several years ago, Joseph E. Stiglitz and Bruno S. Frey suggested an interesting solution to this problem. They maintain that it disappoints government, as well as the market. Stiglitz claims that the state should intervene only in cases when it has the ability to reduce market failure. He postulates government and market co-operation, which can result in their reinforcement and effective solutions for social problems. However, Frey notices that only a powerful nation is able to make rules for an economic game, which enable private markets to operate well. Each time, comparative analysis of costs and profits of market and state operating should make a decision which enables allocation mechanisms to choose. 
